\title{
In Vitro Evaluation of Enterococcus faecalis Adhesion on Various Endodontic Medicaments
}

\author{
Gloria Denotti ${ }^{1}$, Rosaria Piga ${ }^{1}$, Caterina Montaldo ${ }^{1}$, Matteo Erriu ${ }^{1}$, Francesca Pilia ${ }^{1}$, \\ Alessandra Piras ${ }^{1}$, Massimo De Luca² ${ }^{2}$ and Germano Orrù ${ }^{1, *}$
}

${ }^{I}$ Oral Biotechnology Laboratory (OBL), Dipartimento di Chirurgia e Scienze Odontostomatologiche, Universita' Degli Studi di Cagliari, Cagliari, Italy and ${ }^{2}$ Dipartimento di Scienze Odontostomatologiche, Università La Sapienza, Roma, Italy

\begin{abstract}
E. faecalis in endodontic infection represents a biofilm type of disease, which explains the bacteria's resistance to various antimicrobial compounds and the subsequent failure after endodontic treatment. The purpose of this study was to compare antimicrobial activities and bacteria kinetic adhesion in vitro for three endodontic medicaments with a clinical isolate of E. faecalis. We devised a shake culture which contained the following intracanalar preparations: CPD, Endoidrox (EIX), PulpCanalSealer (PCS); these were immersed in a liquid culture medium inoculated with the microorganism. The shake system velocity was able to prevent non-specific bacteria adhesion and simulated the salivary flow. Specimens were collected daily (from both the medium and medicaments) for 10 days; the viable cells were counted by plate count, while the adhesion index $\mathrm{AI}^{\circ}\left[\right.$ E. faecalis fg DNA] $/ \mathrm{mm}^{2}$ was evaluated in the pastes after DNA extraction, by quantitative real time PCR for the 16S rRNA gene. A partial growth inhibition, during the first 24 hours, was observed in the liquid medium and on the medicaments for EIX and subsequently for CPD (six logs). EIX showed the lowest adhesion coefficient $\left(5 * 10^{2}[\mathrm{fg} \mathrm{DNA}] / \mathrm{mm}^{2}\right)$ for nine days and was similar to the control. PCS showed no antimicrobial/antibiofilm properties. This showed that "calcium oxide" base compounds could be active against biofilm progression and at least in the short term (2-4 days) on E. faecalis cells growing in planktonic cultures.
\end{abstract}

\section{INTRODUCTION}

Enterococcus faecalis (Streptococcus faecalis) is a facultative anaerobic, Gram + cocci group D which is a member of the intestinal microflora [1]. It is currently isolated in a wide variety of human infections such as those of the urinary tract, the bloodstream, the abdomen, the endocardium and in situ foreign devices [2-5]. This organism is certainly the major cause of failure in endodontic treatments [6,7]. It may cause periapical disease, perhaps due to its ability to invade dentinal tubes remaining viable within the tubule; in addition, it is also able to adhere to collagen and may form a biofilm [7]. This organism is able to adhere to several surfaces with different kinetics in a different manner depending on the clinical isolate type [8,9]; the adherence mechanism and subsequent biofilm formation have an important role for bacterial colonization and survival in the host and are implicated in chronic infections [10]. In endodontic infection, $E$. faecalis first adheres to the tissue surfaces by a physical association; in a second step there is permanent bonding by specific bacterial adhesins to complementary receptors on the host surfaces. Once the bacterial cell is bound, it is able to use available nutrients and a biofilm structure is necessary to contend with host defense mechanisms and for resistance

*Address correspondence to this author at the Dipartimento di Chirurgia e Scienze Odontostomatologiche, Università degli Studi di Cagliari, Via Binaghi 4, 09121 Cagliari-Italy; Tel: +39 070537413; Fax: +39 070 537437; E-mail: orru@unica.it to antibacterial treatments. For these reasons, experimental data suggest that viable $E$. faecalis cells can be recovered from root canal systems after an effective chemo-mechanical instrumentation treatment [11-13]. However the coronal seal and the history of teeth harbouring enterococci have rarely been accurately investigated; a more likely recent explanation for the high occurrence of enteroccci in filled root canals is that they enter during or after treatment, the origin of this infection is most likely food [14]. In this contest $E$. faecalis intracanalar infection can be due to salivary contamination during treatment or to inadequate root canal obturation by salivary microleakages [15].

In this work we have studied the in vitro kinetic adhesion of E. faecalis in some endodontic treatments using traditional cultural methods and a novel integrated molecular procedure.

This technique consists of a particular dynamic shake culture system containing three different commercial intracanalar medicaments (see formula in material and methods): CPD EIX, PCS, immersed in a liquid medium and inoculated with the microorganism. The shake system velocity was able to oppose non-specific bacterial adhesion simulating the salivary flow in the oral cavity. The cell viability was evaluated by $\mathrm{CFU}$ enumeration, while the adhesion capacity $\left(\mathrm{AI}^{\circ}\right)$ was evaluated by quantitative real time PCR; this molecular technology represents the most sensitive method for recognizing and quantitating bacterial DNA in a short time and 
with high precision. Here we introduce a method for $E$. faecalis adhesion measurement by the quantization of the $16 \mathrm{~S}$ rRNA gene in these endodontic medicaments.

\section{MATERIALS AND METHODOLOGY}

\section{Endontic Materials Used}

Three different endodontic medicaments were used: (i) $\underline{\mathrm{CPD}}$, a recent medicament used in Italy, obtained by mixing three components: Stomilex (Stomigen-Rome, Italy) whose active principle is calcium oxide, Radiopaca iodoformic paste (Giovanni Ogna \& Figli-Muggiò, Mi, Italy) whose active principles are iodoform, parachlorophenol, camphor, menthol and De Trey Zinc (Dentsply, De Trey-Konstanz, Germany); (ii) Endoidrox (EIX) whose active principle is calcium hydroxide; (iii) PulpCanalSealer, PCS (Kerr-USA, Endodontics), whose active principles are zinc oxide and Eugenol.

Each paste was made by following the manufacturer's recommendations and the three components of the CPD paste were mixed in equal parts. These compounds (using $0.25 \mathrm{mg}$ of each Endodontic treatment) did not show any antibacterial activity with this clinical E. faecalis strain in 48 hours by using a conventional Kirby-Bauer diffusion method [16] (data not shown).

\section{Strain Used in this Study}

The Enterococcus faecalis strain used was a clinical isolate $\mathrm{GO} 2$, from endodontic specimens isolated from the Department of Dental Disease Prevention (University of Cagliari). The bacteria were cultured in Müller Hinton agar (MH Microbiol, UTA, Cagliari Italy), and identified by Api 20 Strep (bioMerieuxus Marcy l'etoile, France) [17]. A bacterial suspension was performed to obtain a concentration with a turbidity equivalent to the no. $3 \mathrm{McFarland}$ standard (about $10^{8} \mathrm{CFU} / \mathrm{ml}$ ). Aliquots were stored at $-70^{\circ} \mathrm{C}$ in Müller Hinton broth with $15 \%$ glycerol; this bacterial suspension was used to obtain a genomic DNA standard for a real time quantization curve, and to inoculate shake cultures.

\section{Chemostat Shake Cultures}

The dynamic culture model used (Fig. 1) [18, 19] was an apparatus composed as follows:

(i) shaking table (Continental Instruments, Italy)

(ii) a thermostatic $37^{\circ} \mathrm{C}$ chamber [Vivacar diagnostic, Vivadent, Italy] containing sterile flasks, Falcon 3024 (Becton Dickinson, Meylan Cedèx, France) each with $25 \mathrm{ml}$ of Müller Hinton Broth (three flasks for each endodontic compound).

(iii) each flask contained 10 glass concave supports ( $\varnothing 9$ $\mathrm{mm})$ containing the same endodontic treatment $(0.25 \mathrm{~g})$, the concentration of the endodontic medicament in the medium per flask corresponded to $10 \%$.

(iv) two flasks contained glass vials without any endodontic medicament (negative control samples).

E. faecalis was maintained in a stationary phase for 10 days with a title range mean of $10^{7} \mathrm{CFU} / \mathrm{ml}$ by supplying the flask with an input of new nutrients and the daily removal of liquid medium, 1/3 of total volume (Fig. 1).
We followed the idea that salivary flow rate plays a role in bacterial attachment in teeth and paste surfaces (i.e. during intracanalar restoration) [15]. For this reason the apparatus constructed for this experiment was able to generate a medium flow of approximately $0.5 \mathrm{ml} / \mathrm{min}$ on the medicament surface [20] following the subsequent formula:

$\left[\varnothing=\mathrm{S}_{p} / \mathrm{S} f * \mathrm{Mv} f\right]$

$\varnothing=$ medium flow, $\mathrm{ml} / \mathrm{min}$ in each paste surface

$\mathrm{S}_{p}=$ paste surface $\mathrm{cm}^{2}$

$\mathrm{S} f=$ flask surface $\mathrm{cm}^{2}$

$\operatorname{Mv} f=$ medium flask volume moved in a min, $\mathrm{ml} / \mathrm{min}$

\section{Method for Viable Cell Count}

Viable bacteria were counted from the chemostat liquid medium and from each medicament by diluting samples and plating the dilutions (from $10^{1}$ to $10-^{6}$ ) on Müller Hinton agar.

Each endodontic medicament surface was washed three times with $5 \mathrm{ml}$ of sterile $0.9 \% \mathrm{NaCl}$ solution and successfully scraped by curettage following the procedure indicated by Teles et al. for subgingival plaque [21]. The medicament was suspended in Müller Hinton Broth, vortexed and used for CFU enumeration as described before. The viable cells were expressed as colony-forming units per $\mathrm{ml}, \mathrm{CFU} / \mathrm{ml}$.

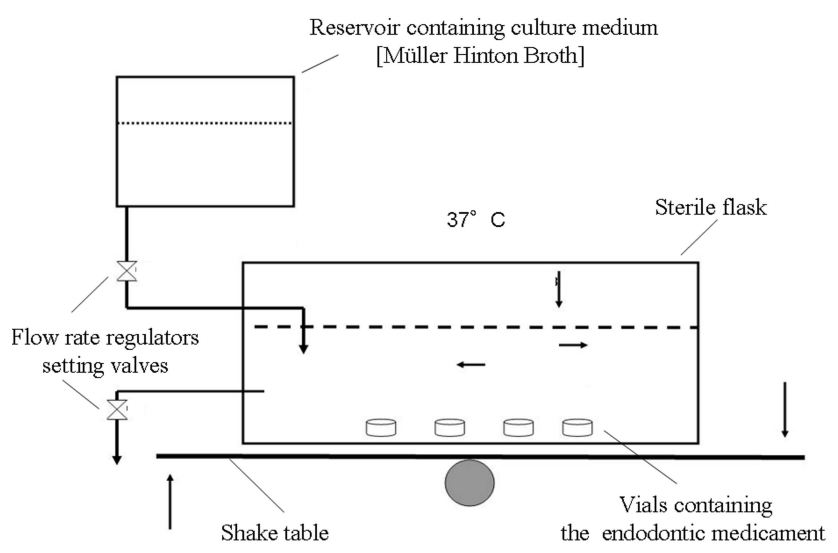

Fig. (1). Schematic representation of the bascule culture system used in this work. The medium level and bacterial title (mean $10^{7}$ cells $/ \mathrm{ml}$ ) were both maintained by the flow rate regulator setting valves.

\section{DNA Extraction}

Once a day for 10 days we collected three vials for each endodontic treatment. After four washes with nuclease-free $\mathrm{H}_{2} \mathrm{O}$, the bacteria were removed from the surface by scraping on the medicament surface, as described previously; they were suspended in $400 \mu \mathrm{l}$ of nuclease-free $\mathrm{H}_{2} \mathrm{O}$ to form a paste suspension. Genomic DNA was obtained by the CTAB modified method [22], using $400 \mu \mathrm{l}$ of each sample (bacteria or paste suspension, After vigorous vortexing, $70 \mu \mathrm{l}$ of sodium dodecyl sulfate (SDS) $10 \%$ and $5 \mu$ l of proteinase K 10 $\mathrm{mg} / \mathrm{ml}$ (SIGMA-Aldrich, ST. Louis Missouri USA) were added; the mixture was incubated for $10 \mathrm{~min}$. at $65^{\circ} \mathrm{C} .100 \mu \mathrm{l}$ 
of $\mathrm{NaCl} 5 \mathrm{M}$ and $100 \mu \mathrm{l}$ of $\mathrm{CTAB} / \mathrm{NaCl}(0,274 \mathrm{M} \mathrm{CTAB}$, and $0,877 \mathrm{M} \mathrm{NaCl}$ ) were subsequently added, and the mixture was then briefly vortexed and incubated at $65^{\circ} \mathrm{C}$ for 10 minutes. $750 \mu \mathrm{l}$ of SEVAG (Chloroform:Isoamyl Alcohol 24:1, SIGMA) were added and the mixture was vortexed for $10 \mathrm{sec}$. After centifugation for $5 \mathrm{~min}$ (at $12000 \mathrm{rpm}$ ) $0.6 \mathrm{vol}-$ umes of isopropanol (SIGMA) were added to the supernatant. After $30 \mathrm{~min}$ at $-20^{\circ} \mathrm{C}$ and centrifugation for $30 \mathrm{~min}$ at $12.000 \mathrm{rpm}$, the pellet was dried at room temperature for 20 min and suspended in $15 \mu \mathrm{l}$ of molecular biology grade distilled water (Gibco, Invitrogen, Paisley, Scotland, UK). E. faecalis genomic DNA obtained from the bacteria suspension was quantified by a RNA-DNA calculator (Pharmacia) and expressed as femtograms of E. faecalis DNA. $2 \mu \mathrm{l}$ of this DNA suspension were used in the PCR real time reaction.

\section{Real Time PCR}

Real time PCR was performed using a LightCycler instrument and a LightCycler DNA Master SYBR Green I kit (Roche Diagnostics Mannheim Germany), according to the manufacturer's instructions [23]. The $20 \mu \mathrm{l}$ final volume contained: $4 \mathrm{mM} \mathrm{MgCl} 2,1 \mu \mathrm{M}$ of each primer (OG33OG123) and $2 \mu 1$ of DNA extract. The PCR program was the following: (i) denaturation at $95^{\circ} \mathrm{C}$ for $30 \mathrm{sec}$, (ii) 40 cycles of $0 \mathrm{sec}$ at $95{ }^{\circ} \mathrm{C}, 10 \mathrm{sec}$ at $50{ }^{\circ} \mathrm{C}, 12 \mathrm{sec}$ at $72^{\circ} \mathrm{C}$, (iii) melting curve performed for 0 seconds at $95^{\circ} \mathrm{C}, 45^{\circ} \mathrm{C}, 95^{\circ} \mathrm{C}$. Transition rates were $5^{\circ} \mathrm{C} / \mathrm{s}$ in the $72^{\circ} \mathrm{C}$ segment, $0.1{ }^{\circ} \mathrm{C} / \mathrm{s}$ in the $45^{\circ} \mathrm{C}$ segment and $20^{\circ} \mathrm{C} / \mathrm{s}$ for another step. Fluorescence was detected at the end of the $72^{\circ} \mathrm{C}$ segment in the PCR step (single mode), and at the $45^{\circ} \mathrm{C}$ segment in the melting step (continuous mode) in the F1 channel. During initial optimization of real time reaction, PCR products were analyzed using agarose gel, to ensure correct sample product size, and by a melting curve analysis. The positive reaction showed a $90^{\circ} \mathrm{C} \mathrm{Tm}$ peak.

\section{Primers for Real Time PCR}

Primers for real time PCR were designed using the $16 \mathrm{~S}$ rRNA gene sequence, extracted from the NCBI database GenBank with accession number AY692453. Possible oligonucleotide dimer formation, self-complementarity and annealing temperatures of the primers were calculated using the Oligo program vers. 4 (MedProbe, Oslo, Norway). Real time PCR primers OG 33 ( ${ }^{\prime}$ '-GACTACCAGGGTATCTAATC -3') and OG 123 (5'- AGCAGCCGCGGTAATA -3') amplified a region of $286 \mathrm{bp}$. The theoretical melting temperatures of these oligos (Tms) were calculated using module 1 of the DNA hybridization prediction algorithm program HYTHER http://ozone3.chem.wayne.edu/ [24] with the following sets of parameters: (i) Monovalent cation concentration at $0.05 \mathrm{~mol} / \mathrm{L}$, (ii) $\mathrm{Mg} 2+$ at $0.004 \mathrm{~mol} / \mathrm{L}$, (iii) a concentration of PCR products (Top/Bottom strands) at $10{ }^{7} \mathrm{~mol} / \mathrm{L}$ and (iv) Hybridisation temperature at $37^{\circ} \mathrm{C}$.

\section{Expression of the $\boldsymbol{E}$. faecalis DNA Concentration}

A real time PCR standard curve was made on DNA extracts, obtained from different $E$. faecalis DNA suspensions with concentration ranges $10^{7}-10^{2}$ DNA fg $/ 2 \mu$ l. The amount of bacterial DNA in the endodontic extracts was calculated by an interpolated threshold cycle with a standard curve
$\left(\mathrm{Y}=-5,4 \mathrm{X}+40,4, \mathrm{R}^{2}=0,98\right)[23]$. We used the following equation to calculate the $E$. faecalis adhesion index:

$\mathrm{AI}^{\circ}=\left([\mathrm{DNA}]^{*} \mathrm{~V}^{\circ} / 2\right) / \mathrm{S}^{\circ}$

$\mathrm{AI}^{\circ}$ is the bacterial adhesion coefficient measured in $\mathrm{fg}$ $\mathrm{DNA} / \mathrm{mm}^{2}$ endodontic compound surface.

[DNA $]=$ fg DNA in $2 \mu 1$, calculated by PCR real time standard curve interpolation.

$\mathrm{V}^{\circ}=$ volume of DNA extract suspension $(15 \mu \mathrm{l}$ during our experiments). $\mathrm{S}^{\circ}=$ medicament surface $\left(19.6 \mathrm{~mm}^{2}\right)$.

\section{RESULTS AND DISCUSSION}

Recent hypotheses indicate that $E$. faecalis is introduced into the oral cavity in food or by operators during endodontic therapy. It can be spread by saliva in filled root canals during intracanalar treatments or by teeth lesions [14]; an association between biofilm formation and virulence has been reported for E. faecalis during dental root infection [25]. Its adherence to a dental surface is controlled by a number of variables including surface structures, nutrient availability, quorum sensing molecules and general fluid hydrodynamics [26]. Primary attachment of bacteria to a surface is mediated by non-specific interactions such as hydrophobic or Van der Wall's forces, however with dental surfaces molecular adhesions are necessary. The liquid flow normally opposes non specific interactions but "at the same time" can be a stimulus for the transition from the planktonic, free-swimming, mode of existence to a mature biofilm $[27,28]$. We have made an in vitro model consisting of a shake $E$. faecalis culture containing three different endodontic medicaments. This system mimics an E. faecalis biofilm on endodontic sealers, and the medium flow/turbulence (simulating saliva in the oral cavity) was an important stimulus for biofilm modulation. In these experiments we observed two major events in nine days: (i) variations in microbial growth, (ii) variations in mass biofilm formation on the medicament surfaces. The antimicrobial activity of endodontic medicaments has been tested using various cultural methods [29]; these studies were however restricted to testing of the initial activity of the materials and their components and were tested by the diffusion Kirby Bauer method at the inhibitory concentrations. The concentrations used in medicaments reported in this work following the manufacturer's instructions, showed no inhibitory effects on Müller Hinton in 48 hours with this clinical E. faecalis strain. However, as reported in Fig. (2), a good partial inhibition (six logs) within the first day, was observed on the MH liquid medium for CPD and EIX, with about $500 \mathrm{CFU} / \mathrm{ml}$ on $2 * 10^{7} \mathrm{CFU}$ in the medium without medicaments (control). CPS showed a 1 log max of inhibition at the first day culture and comparable results were observed by viable $E$. faecalis cell count on medicament surfaces; EIX showed the lowest CFU from the first to the fourth day (about $500 \mathrm{CFU} /$ medicament). Subsequently the strain showed a progressive adaptation to the pastes (from the fourth day on). As has also been suggested by different authors [30] this microorganism showed a contradictory resistance profile against many endodontic medicaments, in particular with strains recovered in different growth phases or when specimens were compared; this explains the notable differences between different authors on comparing the same substance using different $E$. faecalis strains [31,32]. In our 
model E. faecalis showed the lowest adaptability or adhesion propriety with EIX followed by CPD; in the present paper these results have also been confirmed with molecular tools. Fig. (3) shows the E. faecalis DNA expressed as the adhesion index (AI) calculated by real time PCR with the three different compounds for nine culture days. This strain showed a different ability for biofilm formation and no bacterial DNA was detectable during the first hour of incubation (< 100 DNA copies/PCR); detection was however possible after 24 hours. PCS showed an increased bacterial adhesion during the first 48 hours with a subsequent decrease in the following days reaching its lowest point on the seventh day, after which there was a marked increase until the ninth day. The maximum adhesion index was reported on the ninth day: $\mathrm{AI}^{\circ}=2.9^{*} 10^{4}$. The adhesion of bacteria to the CPD paste remained at a low level for the first 48 hours, the highest count of total adhering bacteria was recorded on the seventh day: $\mathrm{AI}^{\circ}=2.7 * 10^{3}$ fg of E. faecalis DNA $/ \mathrm{mm}^{2}$, (Fig. 3). EIX showed the lowest adhesion process, with the range and title between 200 and $500 \mathrm{fg}$ E. faecalis DNA/ $\mathrm{mm}^{2}$ over nine days. In this model, cultural (viable cells) and molecular $\left(\mathrm{AI}^{\circ}\right)$ methods demonstrated that medicaments containing Calcium base compounds $\mathrm{Ca}(\mathrm{OH})_{2} / \mathrm{CaO}$ were most effective
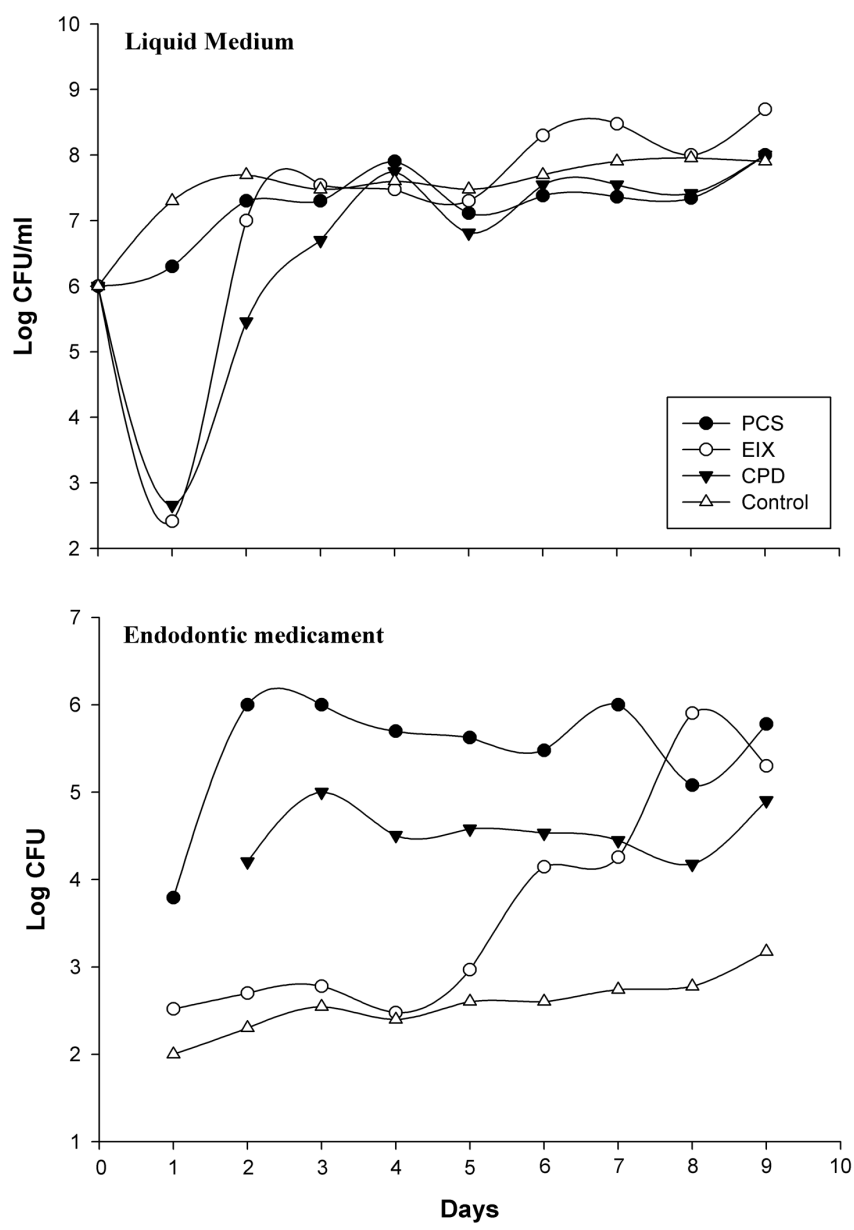

Fig. (2). Growth curves of E. faecalis in medium and in each endodontic medicament reported for shake culture over nine day; each point represents the arithmetic mean of three determinations. The viable cells were expressed as colony-forming units in $\mathrm{ml}$ per liquid medium and in CFU/entire medicament surface $\left(19.6 \mathrm{~mm}^{2}\right)$.

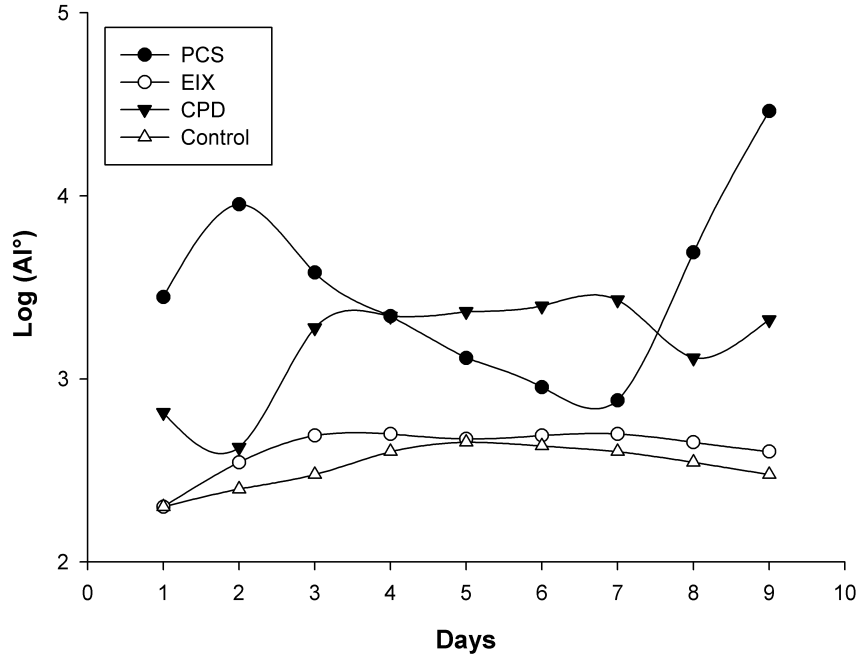

Fig. (3). E. faecalis adhesion kinetic curves for the three endodontic compounds tested in this work. Means and S.D. of at least four experiments are shown.The control samples were concave supports without endodontic medicament and only the highest values are represented.

against microbial growth and against biofilm formation. This is in accordance with Baik et al. 2008 [33] who showed that calcium hydroxide activated $E$. faecalis lipoteichoic acid (LTA), considered a major virulence factor of gram-positive bacteria. Moreover, other authors have demonstrated that this substance in E. faecalis plays a positive role in biofilm formation due to its alanine esters [34].

\section{CONCLUSIONS}

E. faecalis endodontic infection represents a biofilm type of disease where progression of the infection and treatment failure are due to the high adaptability of this bacterial biofilm towards endodontic active compounds. This study, using cultural and molecular techniques, supported the theory of E. faecalis' ability to survive in these compounds; furthermore, it showed that calcium oxide base compounds could be active against biofilm progression, at least in the short term (2-4 days). This approach could be applied to new antimicrobials, as well as to "in vivo" analyses of teeth extracted after failed pulp therapy

\section{REFERENCES}

[1] Tannock GW, Cook G. Enterococci as members of the intestinal microflora of humans. In: Gilmore MS Ed. The Enterococci phatogenesis, molecular biology and antibiotic resistance. Washington DC, ASM press 2002; pp. 101-32.

[2] Graninger W, Ragette R. Nosocomial bacteremia due to Enterococcus faecalis without endocarditis. Clin Infect Dis 1992; 15: 4957.

[3] Sijpkens YW, Buurke EJ, Ulrich C, van Asselt GJ. Enterococcus faecalis colonisation and endocarditis in five intensive care patients as late sequelae of selective decontamination. Intensive Care Med 1995; 21: 231-34.

[4] Khardori N, Wong E, Carrasco CH, Wallace S, Patt Y, Bodey GP. Infections associated with biliary drainage procedures in patients with cancer. Rev Infect Dis 1991; 13: 587-91.

[5] Sandoe JA, Witherden IR, Au-Yeung HK, Kite P, Kerr KG, Wilcox MH. Enterococcal intravascular catheter-related bloodstream infection: management and outcome of 61 consecutive cases. J Antimicrob Chemother 2002; 50: 577-82. 
[6] Pinheiro ET, Gomes BP, Ferraz CC, Sousa EL, Teixeira FB, Souza-Filho FJ. Microorganisms from canals of root-filled teeth with periapical lesions. Int Endod J 2003; 36: 1-11.

[7] Love RM. Enterococcus faecalisa mechanism for its role in endodontic failure. Int Endod J 2001; 34: 399-405.

[8] Kristich CJ, Li YH, Cvitkovitch DG, Dunny GM. Esp-independent biofilm formation by Enterococcus faecalis. J Bacteriol 2004; 186 : 154-63.

[9] Di Rosa R, Creti R, Venditti M, et al. Relationship between biofilm formation, the Enterococcal surface protein (Esp) and gelatinase in clinical isolates of Enterococcus faecalis and Enterococcus faecium. FEMS Microbiol Lett 2006; 256: 145-50.

[10] Costerton JW, Stewart PS, Greenberg EP. Bacterial biofilms: a common cause of persistent infections. Science 1999; 284: 131822

[11] Jenkinson HF, Lamont RJ. Streptococcal adhesion and colonization. Crit Rev Oral Biol Med 1997; 8: 175-200.

[12] Bystrom A, Sundqvist G. The antibacterial action of sodium hypochlorite and EDTA in 60 cases of endodontic therapy. Int Endod J 1985; 18: 35-40.

[13] Buck RA, Eleazer PD, Staat RH, Scheetz JP. Effectiveness of three endodontic irrigants at various tubular depths in human dentin. J Endod 2001; 27: 206-8.

[14] Zehnder M, Guggenheim B. The mysterious appearance of Enterococci in filled root canals. Int Endod J 2009; 42: 277-87.

[15] Heling I, Gorfil C, Slutzky H, Kopolovic K, Zalkind M, SlutzkyGoldberg I. Endodontic failure caused by inadequate restorative procedures: review and treatment recommendations. J Prosthet Dent 2002; 87: 674-8.

[16] Bauer AW, Perry DM, Kirby WM. Single-disk antibioticsensitivity testing of Staphylococci: an analysis of technique and results. AMA Arch Intern Med 1959; 104: 208-16.

[17] Hancock HH, Sigurdsson A, Trope M, Moiseiwitsch J. Bacteria isolated after unsuccessful endodontic treatment in a North American population. Oral Surg Oral Med Oral Pathol Oral Radiol Endod 2001; 91: 579-86

[18] Hills BP, Wright KM. A new model for bacterial growth in heterogeneous systems. J Theor Biol 1994; 168: 31-41.

[19] Marsh PD, Hunter JR, Bowden GH, et al. The influence of growth rate and nutrient limitation on the microbial composition and biochemical properties of a mixed culture of oral bacteria grown in a chemostat. J Gen Microbiol 1983; 129: 755-70.

[20] Edgar WM. Saliva: its secretion, composition and functions. $\mathrm{Br}$ Dent J 1992; 172: 305-12
[21] Teles FR, Haffajee AD, Socransky SS. The reproducibility of curet sampling of subgingival biofilms. J Periodontol 2008; 79: 705-13.

[22] Zhou J, Bruns MA, Tiedje JM. DNA recovery from soils of diverse composition. Appl Environ Microbiol 1996; 62: 316-22.

[23] Rasmussen R. Quantification on the LightCycler. In: Meuer S, Wittwer C, Nakagawara K, Eds. Rapid Cycle Real-Time PCR.Methods and Applications. Berlin: Springer-Verlag 2001; pp. 21-34.

[24] Bommarito S, Peyret N, SantaLucia J Jr. Thermodynamic parameters for DNA sequences with dangling ends. Nucleic Acids Res 2000; 28: 1929-23.

[25] Distel JW, Hatton JF, Gillespie MJ. Biofilm formation in medicated root canals. J Endod 2002; 28: 689-93.

[26] Carniol K, Gilmore MS. Signal transduction, quorum-sensing and extracellular protease activity in Enterococcus faecalis biofilm formation. J Bacteriol 2004; 186: 8161-3.

[27] Siqueira JF Jr., Favieri A, Gahyva SMM, Moraes SR, Lima KC, Lopes HP. Antimicrobial activity and flow rate of newer and established root canal sealers. J Endod 2000; 26: 274-7.

[28] Heydorn AB, Ersboll K, Hentzer M, Parsek MR, Givskov M, Molin S. Experimental reproducibility in flow-chamber biofilms. Microbiology 2000; 146: 2409-15.

[29] Reddy S, Ramakrishna YJ. Evaluation of antimicrobial efficacy of various root canal filling materials used in primary teeth: a microbiological study. Clin Pediatr Dent 2007; 31: 193-8.

[30] Portenier I, Waltimo T, Ørstavik D, Haapasalo M. The susceptibility of starved, stationary phase and growing cells of Enterococcus faecalis to endodontic medicaments. J Endod 2005; 31: 380-6.

[31] Kayaoglu G, Erten H, Bodrumlu E, Ørstavik D. The resistance of collagen-associated, planktonic cells of Enterococcus faecalis to calcium hydroxide. J Endod 2009; 35: 46-9.

[32] Chai WL, Hamimah H, Cheng SC, Sallam AA, Abdullah M. Susceptibility of Enterococcus faecalis biofilm to antibiotics and calcium hydroxide. J Oral Sci 2007; 49: 161-6.

[33] Baik JE, Kum KY, Yun CH, et al. Calcium hydroxide inactivates lipoteichoic acid from Enterococcus faecalis. J Endod 2008; 11 : 1355-9.

[34] Fabretti F, Theilacker C, Baldassarri L, et al. Alanine esters of enterococcal lipoteichoic acid play a role in biofilm formation and resistance to antimicrobial peptides. Infect Immun 2006; 74: 4164

(C) Denotti et al.; Licensee Bentham Open.

This is an open access article licensed under the terms of the Creative Commons Attribution Non-Commercial License (http: //creativecommons.org/licenses/ by-nc/3.0/) which permits unrestricted, non-commercial use, distribution and reproduction in any medium, provided the work is properly cited. 